\title{
Selecting an Own Path: Gender Differences of Self-Employment by Major Industry Groups in Sri Lanka
}

\author{
Gunathilaka, D.K.M. ${ }^{1}$, Samaraweera, G.R.S.R.C. ${ }^{2}$ \\ ${ }^{1,2}$ Department of Economics and Statistics, Sabaragamuwa University of Sri Lanka, \\ Belihuloya, Sri Lanka. \\ ${ }^{1}$ kalpanigunathilaka95@gmail.com, ${ }^{2}$ sumadi@ssl.sab.ac.1k
}

\begin{abstract}
Gender specific diversity of Self-employment is taking place in the labour market, including nearly sixty percent of the informal sector employment in Sri Lanka. Involvement in Selfemployment is higher among males than the females, thus showing the general gender disparity in the Sri Lankan labour market. However, gender specific involvements differ by the nature of self-employment. This study examines the gender differences of selfemployment by major industry groups in Sri Lanka, including agriculture, industry and services. The Sri Lanka Labour Force Survey (2018) conducted by the Department of Census and Statistics was used as the data source and nine binary logistic regression models were applied for the analysis. Results revealed that gender is a significant factor on self-employment choice in each sector. Women are less prone to be selfemployed in the agricultural and services sectors while they are highly prone to be self-employed in the industrial sector. Occupational choices under self-employment also considerably differ for men and women. Gender specific policies were finally suggested to promote self-employment in each major industry groups in Sri Lanka by enhancing awareness, training opportunities and introducing educational reforms in both school and higher education.
\end{abstract}

Keywords: Gender differences, Occupational choice, Self-employment, Major industry groups

Copyright: () 2021 Gunathilaka D.K.M., Samaraweera G.R.S.R.C. This is an open access article distributed under the Creative Commons Attribution License, which permits unrestricted use, distribution, and reproduction in any medium, provided the original work is properly cited.

Correspondence: kalpanigunathilaka95@gmail.com

ORCID of authors: Gunathilaka D.K.M. - (D) https://orcid.org/0000-0001-7367-563X

Samaraweera G.R.S.R.C. - (D) https://orcid.org/0000-0001-7103-2702

DOI: http://doi.org/10.4038/kjm.v10i2.7653 


\section{Introduction}

Self-employment is recognized as starting and running a business or social enterprise successfully on a part time or full-time basis. People choose self-employment to sell their skills or expertise, to prove an idea, to relish the challenges, to generate a second income stream and to react to family pressure and also they are more likely to take risks to gain varieties of benefits such as freedom, being their own boss, earning more money, working fewer hours and independence (Liang, 2011). Self-employment has created major issues in the labour market during the recent decades. It is not only an opportunity for individuals who face various discriminations in the labour market, but it is also an interesting opportunity for individuals who expect to engage in different career paths (Simoes, Crespo \& Moreira, 2016). A number of studies have proven that women are willing to engage in selfemployment mainly due to the flexibility to combine family and their work (Georgellis \& Wall, 2005; Lohmann, 2001). However, Verheul, Thurik, Grilo \& Van der Zwan (2012) stated that in most of the countries, women have a low level of participation in self-employment activities than men due to their lower intentions to be self-employed and gender specific obstacles such as household and family responsibilities.

While self-employment differs in major industry groups, gender intentions also differ in self-employment choice in the agriculture, industry and services sectors in the world. Fields (2013) stated in his study that the share of self-employment is higher in the agriculture sector in developing countries. However, more people become selfemployed in the non-agricultural sector in most of the developed countries. He further stated that the extreme poor in urban areas in most countries engage in non-agricultural businesses as a self-employment option. Sayyar, Latifi, Sarempoor \& Pirmoradi (2012) stated that the average cost that has to be incurred in the agriculture sector is considerably lower than in the industrial sector. Hence, most of the people engage in agriculture related self-employment. Hundley (2001) emphasized that a greater proportion of women are self-employed in less rewarding sectors such as personal services and men are self-employed in higher rewarding sectors such as construction, trade and professional services due to the low level of education and financial ability for females. Women-owned enterprises, which are often characterized as underperformed in literature, focus more on industries such as trade, catering, restaurant and personal services. Those enterprises have comparatively lower chances of survival and growth than men-owned enterprises (Strohmeyer, 2003). Further, the study highlighted the differences in the startup behavior of women and their lower business performance than men due to the lack of human capital for women. Hence, considerable attention should be paid by policy makers on gender differences of selfemployment to tackle the problem of gender inequality of self-employed people in all the major industry groups. According to the Department of Census and Statistics (DCS, 2018), the highest proportion is selfemployed in the agriculture sector while the second highest proportion is self-employed in the services sector. The lowest proportion is self-employed in the industrial sector in Sri Lanka. Participation of men and women in such sectors are also different due to the various demographic, socio-economic and geographical factors.

Hence, this study attempts to examine the gender differences on choosing major industry groups in Sri Lanka for selfemployment while investigating the gender specific factors to identify well-focused policy interventions for enhancing selfemployment options. Specific objectives of the study are to identify the factors associated with self-employment choice of men and women in the agricultural, industrial and services sectors of the Sri Lankan labour market. 


\section{Literature Review}

A number of researchers have identified selfemployment in different ways. Blumberg \& Pfann (2016) have identified that selfemployment is a particular income generating mechanism which vary from wage employment. Further, they stated that self-employed workers perform verities of tasks such as searching and evaluating business opportunities, hiring and firing employees, building and fulfilling contracts, managing and book-keeping. Jovanovic (1982); Lucas, (1978) mentioned that some of the capabilities needed to perform these tasks are inborn. Calvo \& Wellisz (1980) argued that these capabilities are obtained through a learning process.

Significant gender differences in selfemployment were analyzed by most of the researches. Fritsch, Kritikos \& Sorgner (2015) stated that women have less propensity to be self-employed than men due to the differences of the willingness in risk taking and gender specific roles. Gunathilaka \& Samaraweera (2021) also convinced that Sri Lankan and Indian Tamil women, never married women, women with larger household size, tertiary educated women, women with digital literacy, women with higher family income and women living in the rural sector choose self-employment less than that of males in Sri Lanka. Budig (2006) found that women engage less in selfemployment because their earnings in selfemployment are less than that of the men. Gender discriminations from consumers and creditors, gender segregation by industry and occupation and engaging in less lucrative industries due to the use of self-employment as a work and family balancing strategy also cause to have such less willingness of women towards self-employment.

Choice of self-employment differs in major industry groups for men and women. According to Geotz, Fleming \& Rupasingha (2012), in the United States the largest proportion of self-employed is in the professional and business services. The second largest proportion is in the agriculture related sectors. A small share of the selfemployed is in the industrial sector. Bozzoli, Bruck \& Wald (2013) also convinced by studying self-employment in Colombia that people are self-employed concentrating more on the agriculture and services sectors while paying less concentration to the industrial sector. Assuncao (2013) studied selfemployment by major industries in Portugal while comparing them with a few selected countries, and the study stated that the highest percentage of men and women engage in agriculture related selfemployment, the second highest percentage in services-related self-employment and a relatively small share in the manufacturing or industrial related self-employment. The study further declared that Spain and Italy recorded a lower participation of selfemployment in agriculture than Portugal and Greece due to the significant contraction in Spain (Benyuls, Miguelez, Recio, Cano \& Lorente, 2009) and North/South partition of the Italian model of production (Simonazzi, Villa, Lucidi \& Naticchioni, 2009). Assuncao (2013) further asserted that there are more newly established businesses related to the services sector in Spain, Italy and Portugal. In contrast, Southern Europe has a lesser number of newly established businesses related to the services sector. Fritsch et al. (2015) pointed out that self-employment in the services sector has expanded between 1991-2009 with the achievement of higher education and lowering the entry barriers to self-employment while self-employment in the agriculture and forestry, mining, manufacturing, energy and water supply sectors have significantly descended. Although the share of self-employment in the agriculture sector is higher in developing countries, most of the Western nations have a lower percentage of the self-employed only in the agriculture sector due to having classy banking systems, networks of venture capitalists and stock markets (Blanchflower, 2004). Factors associated with gender specific self-employment choice are mainly categorized into three sub sectors as follows, 
and the respective hypotheses are developed accordingly.

\section{Demographic and health determinants on self-employment for men and women by major industry group}

Gender is the most influencing factor on selfemployment among demographic factors (Uddin, Mohammad \& Hammami, 2016). Meeting family needs, self-fulfillment and initiating social relations are three of the most important factors that impact on women for being self-employed (Ufuk \& Ozgen, 2001). Ayele (2014) suggested that most women than men engage in self-employment as a substitute for being unemployed or for part time employment. Further, men and women differ in self-employment due to the choice of various occupations and industries (Budig, 2006). For example, most men choose to become self-employed in science and mathematics related occupations while women choose arts and languages related occupations (Farah, 2014). Patrick, Stephens \& Weinstein (2016) stated that women are less prone to engage in high-risk selfemployment activities than lesser risk wage employment because they tend to be averse to high risks than men. However, Brush, Cater, Gatewood, Greene \& Hart (2006); Hundley (2001); Kepler \& Shane (2007) stated that most of the women are willing to be self-employed in the services sector such as personal services and retail trade and that they are less likely to be self-employed in the manufacturing and high technology industries due to their lesser occupational qualifications and limited time to engage in businesses. Hatfield (2015) stated in her study based on the United Kingdom that the share of women in self-employment has steadily risen, particularly in the administrative and support services and human health and social work related activities. Bozzoli et al. (2013) revealed that more than 50 percentage of self-employed males engage in the agriculture sector while about 10-14 percentage of self-employed are females. Most of the females are self- employed in the services sector, having small shops or restaurants and in the industrial sector in Colombia. When it comes to selfemployment in nonprofessional services, the choice of occupations is different between men and women. Men tend to choose crafts and trade occupations while women are likely to be self-employed in low capital service jobs such as child care providing, hairdressing and sales work sectors (Budig, 2006).

Lofstrom \& Wang (2009) pointed out that ethnic minority entrepreneurs are selfemployed in relatively less attractive industries such as retail trade and personal services and they have less chances to enter human capital-intensive industries such as manufacturing and professional services. Possible reasons for that are lower educational attainments and less financial ability of ethnic minorities. Botric (2012) demonstrated that half of the self-employed are in the agriculture sector and most of them are in elder aged. It indicates that elder aged people are more likely to be self-employed in the agriculture sector to secure necessary means for living. Bozzoli et al. (2013) stated that a larger share of self-employed are in the agriculture sector because children who have farm-owning parents are employed in their farms and after the retirement of the parents, they pass the ownership to their children and thus the children shift from employment to self-employment. This signifies that family background is an influential factor in choosing the industrial sector in selfemployment. According to the above literature, the study can hypothesize that:

H1: Demographic and health factors affecting self-employment choice differ for men and women by major industry groups.

Socio-economic determinants on selfemployment for men and women by major industry group

Choice of industry is basically based on previous experiences and social factors, such 
as certain barriers to the entry and survival in certain sectors and the acceptability of such sectors (Farah, 2014). Garrido (2014) pointed out that the majority of people with higher education are willing to be self-employed in the services sector, the second majority in the industrial sector and a lesser number of people with higher education choose to be self-employed in the agricultural sector. Botric (2012) also showed in her study that less educated people and people with small income are self-employed more in the agriculture sector and it suggests that higher educational background and higher income are not needed to be self-employed in the agriculture sector. Further, she revealed that people having post-secondary education have a higher tendency to be self-employed in the services sector and they have a lower tendency in the manufacturing sector. Lofstrom \& Wang (2009) also stated that some industries need higher level of education such as for the manufacturing and professional services, agriculture, wholesale trade, transportation/ communications, finance/insurance/real estate, business and recreational services to be self-employed and some other industries do not need such levels of education such as for gardening, construction, repair services, retail trade and personal services. They further revealed that industries that require higher educational attainments have higher business survival rates. Daly (2018) studied self-employment amongst aboriginal people and nonaboriginal people in Australia. According to his study, most of the aboriginal people are self-employed in trade occupations and occupations requiring less skills such as plant and machinery operation sectors and as laborers. Other self-employed Australians are self-employed more as managers, administrators and as professionals with higher educational attainments. It concludes that persons with higher educational attainments should be self-employed in higher skilled occupations as mentioned above.
With technological development most of people focus to be self-employed in high-tech services that require relatively low physical capital (Steinmetz \& Wright, 1989). Parker \& Robson (2004) exposed in their study that most of those in countries such as the United States, Canada, Finland, France, Ireland, Italy and Spain are self-employed more in the services sector than in the industry sector due to the advantages of technological factors as explained by the higher self-employment rate in the services sector. The above literature manifests that socio-economic factors affect the choosing of major industry groups in selfemployment and this study explores more of it for men and women also. Hence, the study can assume that:

$\mathrm{H} 2$ : Socio-economic factors affecting selfemployment choice differ for men and women by major industry groups.

\section{Geographical determinants on self- employment for men and women by major industry group}

Non-agricultural self-employment increases while agriculture related self-employment decreases when countries develop and households migrate from rural areas to urban areas (Margolis, 2014). Most of the countries have achieved rapid industrialization with economic growth and it has led the smallscale industries to become large scale industries (Fabayo, 2009). Farah (2014) suggested that most of the rural women engage in subsistence farming and other agricultural activities such as growing vegetables, poultry keeping, tending the family garden etc. Botric (2012) also emphasized that the majority of people who are self-employed in the agriculture sector live in rural areas. Agriculture has been considered as an additional income source and agricultural products have been used for family consumption to maximize earnings by Portugal people living in rural areas (Assuncao, 2013). 
The above literature provides evidence that geographical factors affect the choosing of major industry groups in self-employment for men and women. Thus, the study can postulate that:

H3: Geographical factors affecting selfemployment choice differ for men and women by major industry groups.

Most researchers have conducted their researches on determinants of selfemployment and choice of industry in selfemployment. However, a limited number of researches have conducted to show the impact of health, socio-economic and geographical factors on choosing major industry groups in self-employment and to make a comparison between men and women. In order to compensate this lack of researches, this study focuses on a comparison between men and women on choosing agriculture, industry and services sectors in self-employment in Sri Lanka while identifying the impact of demographic and health, socio-economic and geographical factors.

\section{Methodology}

This study mainly focuses on investigating the gender differences of self-employment in Sri Lanka by major industry groups while studying demographic and health, socioeconomic and geographical factors associated with self-employment for men and women. As mentioned in the literature review, hypotheses were developed with sufficient justifications by getting the literature support to achieve this objective. For testing the hypotheses, an explanatory type research was done by the researcher. Deductive approach was applied by using existing theories without building new theories and the quantitative method was applied by using the binary logistic regression model for analyzing. Secondary data obtained from the Sri Lanka Labour Force Survey (SLLFS) which was conducted by the DCS in 2018 was used as the main data source. 25,750 housing units were used as the sample for this survey using a two-stage stratified sampling technique covering the whole country including all nine provinces in Sri Lanka.

A total of $8,015,166$ employed population in Sri Lanka including 5,300,310 males and 2,714,855 females were selected as the target population and 30,322 employed population that was estimated by the DCS in Sri Lanka for their annual LFS in 2018 including 20,160 males and 10,162 females were selected as the sampling frame of this study. According to the question number 8 in the SLLFS schedule 2018, agriculture, industry and services sectors were identified as major industry groups. 8,158 employed workers including 5,195 male employed workers and 2,963 female employed workers were selected as the sample for the agricultural sector. For the sample of the industry sector, 8,313 employed workers including 5,713 male employed workers and 2,600 female employed workers were chosen and 13,756 employed workers including 9,189 male and 4,567 female employed workers were selected as the sample of the services sector. Nine models were prepared for the agricultural, industry and services sectors separately. It included total, male and female models for each sector. All those models were analyzed using the binary logistic regression model because all the selected dependent variables are qualitative and binary in nature. Demographic and health factors including gender, age, marital status, ethnicity and disability, socio-economic factors including level of education, digital literacy and family income, geographical factors including residential sector and residential province that existed in the SLLFS 2018 were chosen as the explanatory variables for this study by getting the literature support. The STATA statistical package was used to analyze data and the results obtained were presented using tables and texts. 
Common equation of binary logistic regression model for nine logit models of agricultural, industry and services sectors were formulated as follows:

$$
\operatorname{Logit}(\mathrm{Y})=\ln \left(\frac{\mathrm{P}_{\mathrm{i}}}{1-\mathrm{P}_{\mathrm{i}}}\right)=\alpha+\beta_{\mathrm{i}} \mathrm{D}_{\mathrm{i}}+\gamma_{\mathrm{i}} \mathrm{X}_{\mathrm{i}}+\mathrm{u}_{\mathrm{i}}
$$

Self-employment choice in agricultural sector, industry sector and services sector were indicated separately by $\mathrm{Y}$ in this equation and further, these were created for total, male and female models separately. The probability of being self-employed in major industry groups is indicated by $\mathrm{Pi}$ and the probability of not being self-employed in major industry groups is indicated by $1-\mathrm{Pi}$. $\alpha$ denotes the constant and ui denotes the error term. $\beta$ i represents the coefficients of all dummy variables while $\gamma \mathrm{i}$ represents coefficients of all continuous variables. Di and $\mathrm{Xi}$ show Dummy variables and continuous variables respectively including demographic and health, socio-economic and geographical factors for all models. Those are the explanatory variables of this study. Details of those variables are given in Table 2 (Appendix B), Table 4 (Appendix D) and Table 6 (Appendix F) of the descriptive statistics for the agricultural, industry and services sectors respectively.

\section{Findings and Discussion}

Firstly, it was analyzed for identifying the occupations that men and women are mostly engaged in major industry groups. According to the results obtained, Table 1 (Appendix A) on occupations shows that people mostly engage in the agricultural, industry and services sectors for total, men and women with occupation code (Occup. code) and percentage [Percent. (\%)]. Here, occupations have been identified according to occupation codes of the Sri Lanka Standard Classification of Occupation in 2008 (SLSCO-08). Percentage has been taken as a percentage of self-employed people. Total number of observations (Total No. of Obs.) intend the amount of self-employed. The majority of self-employment in overall and male samples in the agricultural sector was paddy growers while tea growers come first for the females in that sector. The majority of industrial self-employment for females are as tailors, fur merchants and hat makers while carpenters and furniture makers are high among the male industrial workers. The majority of self-employments (overall and for females) in services sector are as shop managers while three-wheeler drivers is leading in the male self-employments of the sector. Bozzoli et al. (2013) convinced that most of the women self-employed in the services sector are having small shops or restaurants. As emphasized by Budig (2006), men and women vary by choosing different occupations in self-employment.

Then, descriptive results were obtained for major industry groups in self-employment for total, men and women to identify the impact of demographic and health, socioeconomic and geographical factors that determine the self-employment choice in those sectors as well as to compare it for men and women separately. Those results are shown in Table 2 (Appendix B), Table 4 (Appendix D) and Table 6 (Appendix F) with number of observations, (No. of Obs.), mean or proportion (Mean/Prop.) and standard deviation (Std. Dev.). According to the descriptive results, men's participation in self-employment is higher than that of women's participation in all the major industry groups in Sri Lanka. Gunathilaka \& Samaraweera (2021) asserted in their study that women have a lower participation in selfemployment relative to men due to a number of factors. Mean age of self-employed men and women in the agriculture sector is 48 years. It is 40 years in the industry sector and 41 years in the services sector. It shows that relatively higher aged men and women are self-employed in the agriculture sector. Botric (2012) also has proven this idea. The highest proportion of self-employed men and women in all major industry groups are married and Sinhalese. Descriptive results revealed that higher rate of secondary 
educated men and women and men and women in the rural sector are self-employed in all sectors. A higher proportion of disabled men and women are self-employed in the agriculture sector relative to the other sectors. Women with higher family income are selfemployed at a lower rate in all sectors relative to men.

Moreover, binary logistic regression models were applied for identifying the impact of selected factors on self-employment choice in the agricultural, industry and services sectors for men and women, and they are presented in Table 3 (Appendix C), Table 5 (Appendix E) and Table 7 (Appendix G) including logit coefficient (Logit Coe.), probability value (Prob. Value) and coefficient of marginal effect (Marg. Effect).

\section{Self-employment choice in the agriculture sector}

In the demographic and health aspect, gender is a very important and significant demographic factor that affects the choice of self-employment in the agricultural sector. According to the results shown in Table 3 (Appendix C), women are less likely to choose self-employment in the agricultural sector than men because most of them pursue higher education than men and they are less prone to work as paddy growers like men. Bozzoli et al. (2013); Solotaroff, Joseph \& Kuriakose (2020); Zakaria, Adam \& Abujaja (2014) also have confirmed this result. Age has a significant and positive impact on selfemployment choice in the agricultural sector. When both men and women are getting older, they are more willing to be self-employed in the agricultural sector to earn additional income and meet their family needs because when the household size increases, they have to incur more expenses and they need more money than the younger men and women. By comparison, men are more likely to be selfemployed in this sector than women when they get older because most retired men engage in agriculture related selfemployment as paddy growers, field crops and vegetable growers and tea growers to earn money and spend time leisurely with nature. Botric (2012) confirmed this idea in her study. Zakaria et al. (2014) also revealed that age makes a significant impact to be selfemployed in agribusiness.

Being a never married, a divorced or separated person impact significantly on selfemployment choice for men in this sector. Being a widowed, divorced or separated person impacts significantly on choosing self-employment for women in this sector. Never married, widowed, divorced and separated men have a less likelihood because they do not like to take a high risk to earn money by engaging in agriculture related self-employment due to not having much family issues. However, never married, widowed, divorced and separated women have a greater likelihood to be self-employed in the agricultural sector because such women face more financial problems and they cannot spend more money to be selfemployed in other sectors. Ethnicity is a significantly affecting variable on choosing self-employment in the agricultural sector for both men and women. Results revealed that Tamil and Sri Lankan Moor (SL-Moor) men and women are less likely to be selfemployed in this sector because they have traditionally been engaged in trading to earn more. They have less skills and knowledge about agriculture and do not have sufficient land and space to cultivate agriculture crops like the Sinhalese. According to the results obtained, disability makes a significant impact on the self-employment choice in this sector for women, but not for men. Both disabled men and women show greater willingness to be self-employed in this sector because they can engage in this sector easily with more flexibility and freedom without holding many responsibilities.

Under the socio-economic aspect, the level of education has a significant impact on selfemployment choice in the agricultural sector for both males and females, except having primary education for women. Both men and 
women with primary and secondary education show greater willingness to be selfemployed in this sector relative to the people with no education. This suggests that basic knowledge is a must to be self-employed even in the agricultural sector such as paddy growers, field crops and vegetable growers and tea growers. People with tertiary education have been joined with the people with secondary education due to insufficient cases in tertiary education. However, they are less likely to be self-employed in the agricultural sector when taken as a separate category because with their educational qualifications they are reluctant to engage as paddy growers, field crops and vegetable growers and tea growers. Botric (2012); Garrido (2014) convinced that higher educated people have a lower intention to be self-employed in the agriculture sector. Digital literacy makes a significant and positive impact on self-employment choice in the agricultural sector for both men and women because they can engage in such activities easily without working hard by introducing new equipment and new technical methods using digital literacy. Family income has a significant and positive impact on self-employment choice in the agricultural sector for women, but not for men, because men with higher family incomes think that engaging in agriculture related self-employment as paddy growers, field crops and vegetable growers and tea growers is not suitable for their social status. When family income increases, women do not need to earn more and they have more freedom and flexibility to work with their family by engaging in this sector.

Residential sector is also a significant factor that affected self-employment in the agricultural sector for both men and women except being in the rural sector for females. Men in the rural sector show greater willingness while men in the estate sector show lower willingness to be self-employed in the agricultural sector because people in the rural sector have more knowledge, skills and resources to be self-employed in the agricultural sector than people in urban and estate sectors. Sayyar et al. (2012) also confirmed this result. Women in rural and estate sectors show lower willingness to be self-employed in the agricultural sector because they are employed more in the tea, rubber and coconut associated factories and they are more likely to remain while helping their husbands who are self-employed in the agricultural sector. Zakaria et al. (2014) also revealed that residential sector is a factor that has a significant impact on self-employment choice in agribusiness. All residential provinces make a significant impact on selfemployment choice in the agricultural sector for men, except in the Southern and Sabaragamuwa Provinces. Other provinces except the North Central, Uva and Sabaragamuwa Provinces make a significant impact on self-employment choice in this sector for women. Relative to the Western Province, men in all the provinces except the Southern Province are more likely to be selfemployed in the agricultural sector because those provinces have more rural areas and the Sri Lankan government conducts entrepreneurship development programmes in the agricultural sector while based on rural areas. However, women in the Northern, Eastern and North Central Provinces are more likely to be self-employed in this sector because paddy, field crops and vegetables are grown more in those provinces.

\section{Self-employment choice in the industry sector}

Tailors, fur merchants and hat makers, bakers, flour-based food makers and confectioners, craftsmen, sewers, embroiderers and allied workers, shoe makers and allied workers, potters and allied workers are included in self-employment in the industry sector. As presented in Table 5 (Appendix E), gender makes a significant influence to be self-employed in the industry sector. Most women show a slightly higher likelihood to be self-employed in this sector than men because they have inborn skills and knowledge to work in such fields than men. 
Bozzoli et al. (2013) also convinced that females have a greater likelihood to be selfemployed in the industry sector. Age also has a significant impact on the self-employment choice in this sector. When both men and women get older, they tend to be selfemployed in this sector and also in the agricultural sector because when they get older, they gain more experience, more capital to be self-employed and they suffer from various kinds of disabilities. Kamhi \& Leung (2005) also proved this result.

Results revealed that being a never married, divorced or separated person has a significant impact on self-employment choice in the industry sector for men. However, only being a never married person has a significant impact for women on self-employment choice in this sector. Never married, divorced and separated men and women and widowed women are less likely to be self-employed in this sector relative to married men and women because they do not have the ability to spend more money at the beginning to collect starting capital due to not having their spouse's support. However, widowed men have a greater likelihood to be self-employed in this sector because they have no responsibilities as widowed women. When considering ethnicity, being a SL-Moor significantly impacts the self-employment choice in the industry sector for both men and women, while being a Tamil significantly impacts on choosing self-employment only for women, but not for men. Tamil women are more likely to be self-employed in the industry sector because they have insufficient education to be paid employees in this sector and they have good skills related to making various foods and sweets. Tamil men are less likely to be self-employed in this sector because more of them are employed while associated with estates. SL-Moor men and women are more likely to be self-employed in this sector because they engage more as jewelry and fine metal makers, bakers, flourbased food makers and confectioners and shoe makers and allied workers in the industry sector. Disability has an insignificant and positive impact on selfemployment choice for both men and women because they find it difficult to get paid employment opportunities in the industry sector and they do not have the ability to engage in those employments due to their disability conditions. They like more to engage as tailors, fur merchants and hat makers, bakers, flour-based food makers and confectioners, craftsmen (wood, cane and allied materials), potters and allied workers etc. in this sector due to their disability conditions.

When explaining the impact of education, having tertiary education for men has only a significant impact on self-employment choice in this sector. Men with primary and secondary education are more likely to be self-employed because they have a sufficient knowledge to be self-employed in this sector than men without education. Men with tertiary education are less likely to be selfemployed in this sector because they are more likely to be paid employees in industry sector. Further, this study revealed that women with primary education are less likely to be self-employed. Women with secondary and tertiary education are more likely to be self-employed in this sector because they are trying more to start their own business with their inborn skills and education to earn more in the industry sector. Digital literacy has an insignificant and positive effect on the selfemployment choice in this sector because they can start their own manufacturing businesses easily with the support of new technology. Skalamera-Alilovic, Blecich \& Blazekovic, (2017) also exposed that most of the people with technical knowledge engage in industry related self-employment. Family income makes a significant impact to be selfemployed in this sector only for women, but not for men. When family income rises, men have a greater likelihood to be self-employed in this sector than women because men have sufficient capital with family support to be self-employed in this sector, while women are reluctant to take risks by engaging as tailors, fur merchants and hat makers, bakers, 
flour-based food makers and confectioners, craftsmen etc. in this sector when their family income rises.

Residential sector is a significantly affected variable on self-employment choice in the industry sector for both men and women except being in a rural sector for men. Both men and women in rural and estate sectors are less likely to be self-employed in this sector relative to the urban sector because there are less infrastructure facilities and less ability to access inputs in those sectors to start an own business in the industry sector. Also, people in rural and estate sectors face difficulties when they sell manufactured goods because the market is far from them. Margolis (2014) stated that people shift from agriculture employment to non-agriculture employment when they migrate from rural areas to urban areas. Other provinces except the Southern, Eastern and Sabaragamuwa Provinces make a significant impact for men while the other provinces except the Central, Eastern, Uva and Sabaragamuwa Provinces make a significant influence on women to be self-employed in the industry sector. Relative to the Western Province, men in all the provinces and women in other provinces except the Sabaragamuwa Province are more likely to be self-employed in this sector because the Sri Lankan government conducts self-employment development programmes related to the industry sector and provides subsidies based on other provinces than the Western Province as the poorer and middleincome earning people are in such provinces and also paid employment opportunities in this sector are less in those provinces due to less infrastructure facilities.

\section{Self-employment choice in the services sector}

Self-employment in the services sector comprises three-wheeler drivers, shop managers (active owners), street vendors (except food), car, taxi and van drivers, commercial and sales agents, meat vendors, fishmongers and allied chefs, heavy truck and lorry drivers, car mechanics and repairmen etc. Based on the results outlined in Table 7 (Appendix G), gender significantly impacts on self-employment choice in the services sector. Most men than women are selfemployed in this sector because men have skills related to services than women and they have a lower confidence and lower awareness to start their own businesses related to the services sector. Age makes a significant impact on self-employment choice in the services sector also. Older men and women are more likely to be self-employed in this sector because they have more experience and capital to start businesses related to providing services.

When explaining the influence of marital status, only being a never married person has a significant impact for men and being never married and being widowed have a significant impact for women to be selfemployed in the services sector. Never married and widowed men and never married women show less willingness and divorced and separated men and widowed, divorced and separated women have a higher willingness to be self-employed in this sector relative to the married. Never married men and women have no family issues like married people. Hence, they do not want to take a risk by engaging services-related selfemployment. Widowed women face more family issues than widowed men as they do not have the support from their spouses. They have to earn money and care for their children and parents alone. Hence, they engage more in self-employment in the services sector. Divorced and separated men and women also have more responsibilities and hence engaging as commercial and sales agents, secondary education teachers, beauticians, mechanics and repairmen is better for them because it gives them freedom and flexibility to manage their family work as well.

Being a SL-Moor makes a significant impact while being a Tamil makes an insignificant impact on choosing self-employment in the 
services sector for both men and women. Tamil men and women are less likely to be self-employed in this sector because they are employed more in the estate sector, especially related to tea factories in Sri Lanka. SL-Moor men and women are more likely to be self-employed in this sector because they work while giving priority to trading and they import more items such as jewelries, finished clothes, fancy items etc. and trade those items in the Sri Lankan market. Lofstrom \& Wang (2009) also asserted that ethnic minority people are more likely to be self-employed in nonprofessional services such as trading due to the lower education and financial constraints. Disability creates a significant effect on selfemployment choice in the services sector only for men, but not for women. Both disabled men and women show greater willingness to be self-employed in this sector as lottery sellers and street vendors because services-related companies do not like to recruit disabled people as workers to supply their services to their customers.

Tertiary education for men, secondary and tertiary education for women makes a significant impact on being self-employed in this sector. Men and women with primary and secondary education are more likely to be self-employed in this sector because only having primary and secondary education is not sufficient to get a better job within the job market in this sector due to the competition. Hence, they have to engage in selfemployment. Most of the men and women with tertiary education are less likely to be self-employed in this sector because they try to engage in well-established jobs that match with their qualifications in this sector without engaging as three-wheeler drivers, street vendors, car, taxi and van drivers, meat vendors, fishmongers and allied chefs, heavy truck and lorry drivers, car mechanics and repairmen etc. Digital literacy makes a significant and negative impact on choosing self-employment in the services sector due to more paid employment opportunities and a good job market with higher salaries in this sector. Parker \& Robson (2004) mentioned in their study that most people in developed countries are self-employed in the services sector by getting the benefit of technological development. However, more people in developing countries such as Sri Lanka are self-employed less in this sector because people do not have sufficient knowledge to be self-employed using technology. Further study revealed that family income has an insignificant and negative impact on selfemployment choice in the services sector because there are better salary scales for employment opportunities in this sector and when family income increases, people do not face serious family issues and they do not want to take unnecessary risks by engaging in self-employment. Hence, they engage more in paid employment and are reluctant to be self-employed as family income rises.

Only being a woman in the rural sector has a significant impact on self-employment choice in the services sector. Men and women in the rural sector are more likely to be self-employed in this sector because most of them are Sinhalese and they like to be selfemployed as three-wheeler drivers, commercial and sales agents, secondary education teachers, beauticians and allied workers etc. Men and women in the estate sector are less likely to be self-employed in the services sector because most of them are Tamils and they are mostly employed in tea and rubber factories. Among the residential provinces, the Central, Southern, Northern, North Western and Uva Provinces have a significant impact for men and Eastern, North Western and North Central Provinces have a significant impact for women to be self-employed in this sector. Relative to the Western Province, men in all other provinces other than the Eastern Province and women in all the provinces except the Northern Province are more likely to be self-employed in the services sector. The Eastern and Northern Provinces have not developed well with a better market. People in such provinces engage more in agriculture related self-employment. Hence, they are less likely 
to be self-employed in the services sector. However, more people in other provinces relative to the Western Province become selfemployed due to less education and less paid employment opportunities in those provinces.

\section{Conclusion}

This research was conducted to study the differences between men and women towards self-employment in Sri Lanka by major industry groups while examining demographic and health, socio-economic and geographical factors associated with selfemployment separately for each gender and major industry groups. Secondary data obtained from SLLFS conducted by the DCS in 2018 was used as the main data source and the binary logistic regression model was applied for analyzing the study. According to the results, gender makes a significant impact on self-employment choice in the agricultural, industry and services sectors and women are less prone to be self-employed in the agricultural and services sectors than men. However, women are more prone to be self-employed in the industry sector than men.

Further results revealed that in the demographic and health aspect, age and being disabled positively impact while being Tamil and SL-Moor negatively impact on self-employment in the agriculture sector for both men and women. Being never married, widowed, divorced and being separated positively impact on self-employment in the agricultural sector only for women. Age, being SL-Moor, being disabled have a positive impact while being never married, divorced and separated have a negative impact on self-employment in the industry sector for both men and women. Being widowed positively impacts only for men and being Tamil positively impacts only for women on industrial self-employment. Age, being divorced and separated, being SLMoor, being disabled make a positive impact while being never married and being Tamil make a negative impact on self-employment in the services sector for both men and women. Being widowed makes a positive impact on self-employment in the services sector only for men.

Under the socio-economic aspect, having primary, secondary and tertiary education, having digital literacy positively impact for both men and women while family income positively impacts only for women on selfemployment in the agriculture sector. Having secondary education and having digital literacy impact positively on selfemployment in the industry sector for both men and women. Having primary education and family income impact positively only for men while having tertiary education impacts positively for women on self-employment in the industry sector. Having primary and secondary education positively impact while having tertiary education, having digital literacy and family income negatively impact for both men and women on self-employment in the services sector.

In terms of geographical aspect, being in the Northern, Eastern and North Central Provinces make a positive impact while being in estate sector and being in the Southern Province make a negative impact for both men and women on self-employment in the agriculture sector. Being in the rural sector, being in the Central, North West, Uva and Sabaragamuwa Provinces make a positive impact only for men on selfemployment in the agriculture sector. Being in all other provinces except the Sabaragamuwa Province positively impact while being in rural and estate sectors negatively impact on self-employment in the industry sector for both men and women. Being in rural sector and being in all other provinces except the Northern and Eastern Provinces positively impact, while being in the estate sector negatively impact on selfemployment in the services sector for both men and women. Further, results also exposed that occupational choice in selfemployment also differs for men and women. 
Findings of the research will be important to policy makers for creating gender specific policies related to self-employment by major industry groups to promote self-employment in the agricultural, industry and services sectors in Sri Lanka. According to the results of the study, to enhance women's participation in the agricultural sector, awareness on self-employment for rural women must be enhanced through the Agrarian Services Centers by conducting awareness raising programmes using social media and television channels. New methods can also be introduced for home gardening experiments specially to enhance women's participation in agriculture related selfemployment. For enhancing women's participation in the services sector, knowledge and skills about self-employment for urban women must be enhanced through Urban Councils by conducting awareness raising programmes and organizing training courses at divisional level. To enhance Tamil and SL-Moor men's and women's participation in agriculture related selfemployment, opportunities should be created to be self-employed in the agriculture sector while providing sufficient knowledge and skills through training programmes. Women in rural and estate sectors can be encouraged towards agriculture and industry related selfemployment by providing financial assistance and guidance through Samurdhi Banks, especially to engage in tea growing, field crops and vegetable growing areas in the agriculture sector and tailoring, fur trading, baking, flour-based food making and making confectionary areas in the industry sector. Disabled men and women can also be encouraged further in all sectors by introducing new markets and providing financial and consultation services. For encouraging more educated men and women towards self-employment in each sector, entrepreneurship-based education reforms should be introduced by the Ministry of Education in both secondary and tertiary levels. Men and women with digital literacy can be encouraged towards services-related self-employment by introducing home based new technological self-employment and technological entrepreneurship opportunities with a systematic guidance, knowledge and financial support.

\section{Acknowledgement}

Authors would like to convey their deepest gratitude to the Department of Census and Statistics for providing the micro level data of the Sri Lanka Labour Force Survey in 2018 to undertake this study. 
Gunathilaka, D.K.M., Samaraweera, G.R.S.R.C., KJM, 2021, 10 (02)

\section{References}

Assuncao, F. M. (2013). On becoming self-employed: Gender, class and entrepreneurship in Portugal.

Ayele, A. (2014). Determinants among youth self-employment in selected sub-cities of Addis Ababa (Doctoral dissertation, Addis Ababa University).

Benyuls, J., Miguelez, F., Recio, A., Cano, E., \& Lorente, R. (2009). The transformation of the employment system in Spain: Towards a Mediterranean Neoliberalism?. In G. Bosch, S. Lehndorff and J. Rubery, ed. European Employment Models in Flux. Basingstoke: Palgrave Macmillan, pp. 247-269. https://doi.org/10.1057/9780230237001_10

Blanchflower, D. G. (2004). Self-employment: More may not be better. https://doi.org/10.3386/w10286

Blumberg, B. F., \& Pfann, G. A. (2016). Roads leading to self-employment: Comparing transgenerational entrepreneurs and self-made start-ups. Entrepreneurship Theory and Practice, 40(2), 335-357. https://doi.org/10.1111/etap.12227

Botric, V. (2012). Regional differences in self-employment: evidence from Croatia. Economic $\begin{array}{lll}\text { research-Ekonomska istraživanja, 25(sup1), 243-266. } & \end{array}$ https://doi.org/10.1080/1331677X.2012.11517564

Bozzoli, C., Brück, T., \& Wald, N. (2013). Self-employment and Conflict in Colombia. Journal of Conflict Resolution, 57(1), 117-142. Available at http://hdl.handle.net/10419/52534

Brush, C., Carter, N., Gatewood, E., Greene, P., \& Hart, M. (2006). Women's entrepreneurship in the United States. In Brush, C., Carter, N., Gatewood, E., Greene, P. \& Hart, M. (Eds.) Growth-oriented women entrepreneurs and their businesses, Cheltenham, UK: Edward Elgar.

Budig, M. J. (2006). Gender, self-employment, and earnings: The interlocking structures of family and professional status. Gender \& society, 20(6), 725-753. https://doi.org/10.1177/0891243206293232

Calvo, G., \& Wellisz, S. (1980). Technology, entrepreneurs, and firm size. Quarterly Journal of Economics, 95: 663-677. https://doi.org/10.2307/1885486

Daly, A. E. (2018). Self-employment amongst Aboriginal people. Canberra, ACT: Centre for Aboriginal Economic Policy Research (CAEPR), The Australian National University.

Department of Census and Statistics (2018). Sri Lanka labour force survey: Annual report2018. Colombo, Sri Lanka: DCS.

Fabayo, J. A. (2009). Small and medium enterprises development strategy: A critical option for sustainable long -term economic development in Nigeria. A paper presented at the first Annual International Conference on: Effective Management of Small and Medium scale 
Enterprises for sustainable Economic Development held at Abraham Adesanya Polytechnic, Ijebu-Ode held from 25-27 August.

Farah, A. I. (2014). Factors influencing women participation in entrepreneurial activities in Mandera Township, Mandera Central Division, Kenya. A research project submitted in partial fulfillment of the requirement for the degree of master of arts in project planning and management, school of continuing and distance education, University of Nairobi.

Fields, G. S. (2013). Self-employment in the developing world. Paper submitted to the highlevel panel on the post-2015 development agenda. Cornell University and IZA.

Fritsch, M., S. Kritikos, A., \& Sorgner, A. (2015). Why did self-employment increase so strongly in Germany?. Entrepreneurship \& Regional Development, 27(5-6), 307-333. Available at http://hdl.handle.net/10419/108700

Garrido, J. I. (2014). Self-employment: New empirical evidence on human capital and business cycles.

Georgellis, Y., \& Wall, H. J. (2005). Gender differences in self-employment. International review of applied economics, 19(3), 321-342. https://doi.org/10.1080/02692170500119854

Goetz, S. J., Fleming, D. A., \& Rupasingha, A. (2012). The economic impacts of selfemployment. Journal of Agricultural and Applied Economics, 44(1379-2016-113672), 315321. https://doi.org/10.1017/S1074070800000432

Gunathilaka, D. K. M., \& Samaraweera, G. R. S. R. C. (2021). A Comparative Study of the Choice of Self-employment between Men and Women in Sri Lanka. Sri Lankan Journal of Business Economics, 10(1).

Hatfield, I. (2015). Self-employment in Europe (Vol. 4, pp. 01-15). London: IPPR. Available at http://www.ippr.org/publications/selfemployment-in-europe

Hundley, G. (2001). Why women earn less than men in self-employment. Journal of labor research, 22(4), 817-829. https://doi.org/10.1007/s12122-001-1054-3

Jovanovic, B. (1982). Selection and the evolution of industry. Econometrica,_50(3): 649-670. https://doi.org/10.2307/1912606

Kamhi, N., \& Leung, D. (2005). Recent developments in self-employment in Canada (No. 2005-8). Bank of Canada.

Kepler, E., \& Shane, S. (2007). Are male and female entrepreneurs really that different?. Small Business Advocacy Office Report No. 309.

Laing, D. (2011). Self-employment. University of Manchester, AGCAS.

Lofstrom, M., \& Wang, C. (2009). Mexican-American self-employment: a dynamic analysis of business ownership. In Ethnicity and Labor Market Outcomes. Emerald Group Publishing Limited. https://doi.org/10.1108/S0147-9121(2009)0000029010 
Lohmann, H. (2001). Self-employed or employee, full-time or part-time? Gender differences in the determinants and conditions for self-employment in four European countries and the US. Arbeitspapiere - Mannheimer Zentrum für Europäische Sozialforschung, 38, ISSN 14378574.

Lucas, R. E. (1978). On the size distribution of business firms. Bell Journal of Economics, 9: 508-523. https://doi.org/10.2307/3003596

Margolis, D. N. (2014). By choice and by necessity: Entrepreneurship and self-employment in the developing world. The European Journal of Development Research, 26(4), 419-436. https://doi.org/10.1057/ejdr.2014.25

Parker, S. C., \& Robson, M. T. (2004). Explaining international variations in selfemployment: evidence from a panel of OECD countries. Southern Economic Journal, 287301. https://doi.org/10.2307/4135292

Patrick, C., Stephens, H., \& Weinstein, A. (2016). Where are all the self-employed women? Push and pull factors influencing female labor market decisions. Small Business Economics, 46(3), 365-390. https://doi.org/10.1007/s11187-015-9697-2

Sayyar, L. Z., Latifi, S., Sarempoor, Q., \& Pirmoradi, A. (2012). Factors facilitating entrepreneurship and self-employment in agriculture sector. Life Science Journal-Acta Zhengzhou University Overseas Edition, 9(4), 2423-2430.

Simoes, N., Crespo, N., \& Moreira, S. B. (2016). Individual determinants of self-employment entry: What do we really know?. Journal of economic surveys, 30(4), 783-806. https://doi.org/10.1111/joes.12111

Simonazzi, A., Villa, P., Lucidi, F., \& Naticchioni, P. (2009). Continuity and change in the Italian model. In G. Bosch, S. Lehndorff and J. Rubery, ed. European Employment Models in Flux. Basingstoke: Palgrave Macmillan, pp. 201-222. https://doi.org/10.1057/9780230237001_8

Skalamera-Alilovic, D., Blecich, A. A., \& Blazekovic, K. (2017). Self-employment: Personal characteristics of the self-employed and impact on economic growth. In Interdisciplinary Management Research Conference Xiii.

Solotaroff, J. L., Joseph, G., \& Kuriakose, A. T. (2020). Unlocking women's potential in Sri Lanka's labor force. World Bank Group. https://doi.org/10.1596/978-1-4648-1067-1

Steinmetz, G., \& Wright, E. O. (1989). The fall and rise of the petty bourgeoisie: Changing patterns of self-employment in the postwar United States. American journal of Sociology, 94(5), 973-1018. https://doi.org/10.1086/229110

Strohmeyer, R. (2003). Gender differences in self-employment: Does education matter. Proceedings of the $48^{\text {th }}$ International Council for Small Business (ICSB): Advancing Entrepreneurship and Small Business, Belfast.

Uddin, M. A., Mohammed, S., \& Hammami, S. (2016). Influence of demographic factors on the entrepreneurial intentions of university students in Oman. Investment Management and Financial Innovations, 13(1), 215-220. 
Gunathilaka, D.K.M., Samaraweera, G.R.S.R.C., KJM, 2021, 10 (02)

Ufuk, H. \& Ozgen, O. (2001). The profile of women entrepreneurs: A sample from Turkey. Journal of Consumer Studies and Home Economics, 25(4), p. 299-308. https://doi.org/10.1046/j.1470-6431.2001.00197.x

Verheul, I., Thurik, R., Grilo, I., \& Van der Zwan, P. (2012). Explaining preferences and actual involvement in self-employment: Gender and the entrepreneurial personality. Journal of economic psychology, 33(2), 325-341. https://doi.org/10.1016/j.joep.2011.02.009

Zakaria, H., Adam, H., \& Abujaja, A. M. (2014). Assessment of agricultural students of university for development studies intention to take up self-employment in agribusiness. 


\section{Appendices}

\section{Appendix A}

Table 01: Occupational choice of self-employment in agricultural, industry and services sectors for total, male and female models

\begin{tabular}{|c|c|c|c|c|c|c|c|c|c|c|c|c|c|c|c|c|c|}
\hline \multicolumn{6}{|c|}{ Agricultural sector } & \multicolumn{6}{|c|}{ Industry sector } & \multicolumn{6}{|c|}{ Services sector } \\
\hline \multicolumn{2}{|c|}{ Total } & \multicolumn{2}{|c|}{ Male } & \multicolumn{2}{|c|}{ Female } & \multicolumn{2}{|c|}{ Total } & \multicolumn{2}{|c|}{ Male } & \multicolumn{2}{|c|}{ Female } & \multicolumn{2}{|c|}{ Total } & \multicolumn{2}{|c|}{ Male } & \multicolumn{2}{|c|}{ Female } \\
\hline $\begin{array}{c}\text { Occu } \\
\text { p. } \\
\text { code }\end{array}$ & $\begin{array}{c}\text { Percent } \\
.(\%)\end{array}$ & $\begin{array}{l}\text { Occup } \\
\text {. code }\end{array}$ & $\begin{array}{c}\text { Percent } \\
.(\%)\end{array}$ & $\begin{array}{l}\text { Occup } \\
\text {. code }\end{array}$ & $\begin{array}{c}\text { Percent } \\
.(\%)\end{array}$ & $\begin{array}{l}\text { Occup } \\
\text {. code }\end{array}$ & $\begin{array}{c}\text { Percent } \\
.(\%)\end{array}$ & $\begin{array}{l}\text { Occup } \\
\text {. code }\end{array}$ & $\begin{array}{c}\text { Percent } \\
.(\%)\end{array}$ & $\begin{array}{l}\text { Occup } \\
\text {. code }\end{array}$ & $\begin{array}{c}\text { Percent } \\
.(\%)\end{array}$ & $\begin{array}{l}\text { Occup } \\
\text {. code }\end{array}$ & $\begin{array}{c}\text { Percent } \\
.(\%)\end{array}$ & $\begin{array}{l}\text { Occup } \\
\text {. code }\end{array}$ & $\begin{array}{c}\text { Percent } \\
.(\%)\end{array}$ & $\begin{array}{l}\text { Occup } \\
\text {. code }\end{array}$ & $\begin{array}{c}\text { Percent } \\
.(\%)\end{array}$ \\
\hline 6113 & 21.52 & 6113 & 25.96 & 6114 & 26.23 & 7531 & 20.82 & 7115 & 12.72 & 7531 & 44.5 & 1420 & 20.35 & 8323 & 21.33 & 1420 & 28.78 \\
\hline 6114 & 16.28 & 6111 & 15.37 & 6111 & 11.51 & 7115 & 7.6 & 7116 & 9.97 & 7512 & 10.85 & 8323 & 16.69 & 1420 & 17.93 & 3322 & 6.54 \\
\hline 6111 & 14.5 & 6114 & 13.39 & 6411 & 7.68 & 7512 & 6.17 & 7412 & 5.12 & 7316 & 8.14 & 9520 & 5.61 & 9520 & 5.58 & 9520 & 5.73 \\
\hline 6411 & 9.96 & 6411 & 10.62 & 6121 & 7.04 & 7116 & 5.96 & 7531 & 4.85 & 7516 & 4.07 & 3322 & 4.77 & 8322 & 4.29 & 2342 & 5.16 \\
\hline 6117 & 5.17 & 6117 & 4.69 & 6117 & 6.82 & 7316 & 3.88 & 7131 & 3.48 & 7533 & 3.93 & 7511 & 3.41 & 3322 & 4.26 & 5211 & 4.24 \\
\hline 6112 & 4.04 & 6224 & 4.22 & 9212 & 6.72 & 7412 & 3.06 & 7212 & 3.2 & 7536 & 2.71 & 8322 & 3.36 & 7511 & 3.9 & 7512 & 4.13 \\
\hline 6121 & 3.87 & 6112 & 3.88 & 6113 & 6.29 & 7313 & 2.35 & 7512 & 3.02 & 7317 & 2.31 & 8332 & 2.67 & 8332 & 3.43 & 2330 & 3.9 \\
\hline 6224 & 3.27 & 6119 & 3.23 & 6118 & 5.54 & 1321 & 2.08 & 7313 & 2.47 & 7313 & 2.17 & 5211 & 2.36 & 7231 & 2.91 & 5142 & 3.44 \\
\hline 6119 & 2.89 & 6121 & 2.95 & 6112 & 4.58 & 7131 & 2.08 & 1321 & 2.29 & 7319 & 2.17 & 7231 & 2.28 & 3324 & 2.77 & 1439 & 2.29 \\
\hline 6118 & 2.12 & 9211 & 1.65 & 6122 & 4.26 & 7212 & 1.91 & 7312 & 2.1 & 1321 & 1.76 & 3324 & 2.18 & 1439 & 2.05 & 1412 & 2.18 \\
\hline $\begin{array}{l}\text { Total } \\
\text { No. of } \\
\text { Obs. }\end{array}$ & 4158 & & 3220 & & 938 & & 1830 & & 1093 & & 737 & & 3901 & & 3029 & & 872 \\
\hline
\end{tabular}

Source: Researcher's calculations using micro data, 2018 
Notes: Description of Occupation codes (According to SLSCO-08):

- Agricultural sector

$6111=$ Field crops and vegetable growers (Except cereals, plantation crops and minor export crops)-for trade

$6112=$ Growers of grain crops (Except paddy) - for trade

$6113=$ Paddy growers - for trade

$6114=$ Tea growers - for trade

$6117=$ Growers of minor export crops - for trade

$6118=$ Home gardeners, garden and nursery growers - for trade

$6119=$ Mixed crop growers - for trade

$6121=$ Animal and dairy producers - for trade

$6122=$ Poultry producers - for trade

$6224=$ Fishermen on sea - for trade

$6411=$ Farmers cultivating paddy and vegetables for subsistence

$9211=$ Crop farm workers (Ex: coconut pluckers, toddy tappers)

$9212=$ Tea pluckers

\section{- Industrial sector}

$1321=$ Production managers (Active owners)

$7115=$ Carpenters and furniture makers

$7116=$ Masonry (Ordinary)

$7131=$ Painters and allied workers

$7212=$ Welders and flame cutters

$7312=$ Jewelry and fine metal makers

$7313=$ Potters and allied workers

$7316=$ Craftsmen (Wood, cane and allied materials)

$7317=$ Craftsmen (Fabrics and related materials)

$7319=$ Other artisans (ex: Artificial flower makers, broom makers, brush makers etc.)

$7412=$ Electricians and welders

$7512=$ Bakers, flour-based food makers and confectioners

$7516=$ Tobacco makers and manufacturers of tobacco products

$7531=$ Tailors, fur merchants and hat makers

$7533=$ Sewers, embroiderers and allied workers 
$7536=$ Shoe makers and allied worker

1412 = Restaurant managers (Active owners)

$1420=$ Shop managers (Active owners)

1439 = Services managers (Active owners)

$2330=$ Secondary education teachers

2342 = Educators of early childhood

$3322=$ Commercial and sales agents (Ex: Retailers and wholesalers)

$3324=$ Trading brokers

$5142=$ Beauticians and allied workers

$5211=$ Shop and market sales workers

7231 = Car mechanics and repairmen

$7511=$ Meat vendors, fishmongers and allied chefs

7512 = Bakers, flour-based food makers and confectioners

$8322=$ Car, taxi and van drivers

$8323=$ Three-wheeler drivers

8332 = Heavy truck and lorry drivers

$9520=$ Street vendors $($ Except food $)$ 


\section{Appendix B}

Table 02: Descriptive statistics for self-employment choice in agricultural sector for total, male and female models

\begin{tabular}{|c|c|c|c|c|c|c|c|c|c|}
\hline \multirow{3}{*}{$\begin{array}{l}\text { Major Industry group } \\
\text { Name of the model } \\
\text { Variable }\end{array}$} & \multicolumn{9}{|c|}{ Agricultural sector } \\
\hline & \multicolumn{3}{|c|}{ Total } & \multicolumn{3}{|c|}{ Male } & \multicolumn{3}{|c|}{ Female } \\
\hline & $\begin{array}{l}\text { No. of } \\
\text { Obs. }\end{array}$ & Mean/Prop. & Std. Dev. & $\begin{array}{l}\text { No. of } \\
\text { Obs. }\end{array}$ & Mean/Prop. & Std. Dev. & $\begin{array}{c}\text { No. of } \\
\text { Obs. }\end{array}$ & Mean/Prop. & Std. Dev. \\
\hline Self-employment choice(D1) & 4,158 & 0.5097 & 0.4999 & 3,220 & 0.6198 & 0.4855 & 938 & 0.3166 & 0.4652 \\
\hline \multicolumn{10}{|l|}{ Explanatory variables } \\
\hline \multicolumn{10}{|l|}{ Gender } \\
\hline Male(D2) & 5,195 & 0.6368 & 0.4810 & - & - & - & - & - & - \\
\hline Female(D3) & 2,963 & 0.3632 & 0.4810 & - & - & - & - & - & - \\
\hline $\operatorname{Age}(X 1)$ & 8,158 & 48.5210 & 13.5661 & 5,195 & 48.5367 & 14.3448 & 2,963 & 48.4934 & 12.0825 \\
\hline \multicolumn{10}{|l|}{ Marital status } \\
\hline Married(D4) & 6,683 & 0.8192 & 0.3849 & 4,347 & 0.8368 & 0.3696 & 2,336 & 0.7884 & 0.4085 \\
\hline Never married(D5) & 795 & 0.0975 & 0.2966 & 670 & 0.1290 & 0.3352 & 125 & 0.0422 & 0.2010 \\
\hline \multicolumn{10}{|l|}{ Ethnicity } \\
\hline Sinhala(D8) & 5,811 & 0.7123 & 0.4527 & 3,534 & 0.6803 & 0.4664 & 2,277 & 0.7685 & 0.4219 \\
\hline Tamil(D9) & 1,955 & 0.2396 & 0.4269 & 1,333 & 0.2566 & 0.4368 & 622 & 0.2099 & 0.4073 \\
\hline SL-Moor(D10) & 392 & 0.0481 & 0.2139 & 328 & 0.0631 & 0.2432 & 64 & 0.0216 & 0.1454 \\
\hline Disabled (D12) & 1,418 & 0.1738 & 0.3790 & 896 & 0.1725 & 0.3778 & 522 & 0.1762 & 0.3810 \\
\hline
\end{tabular}




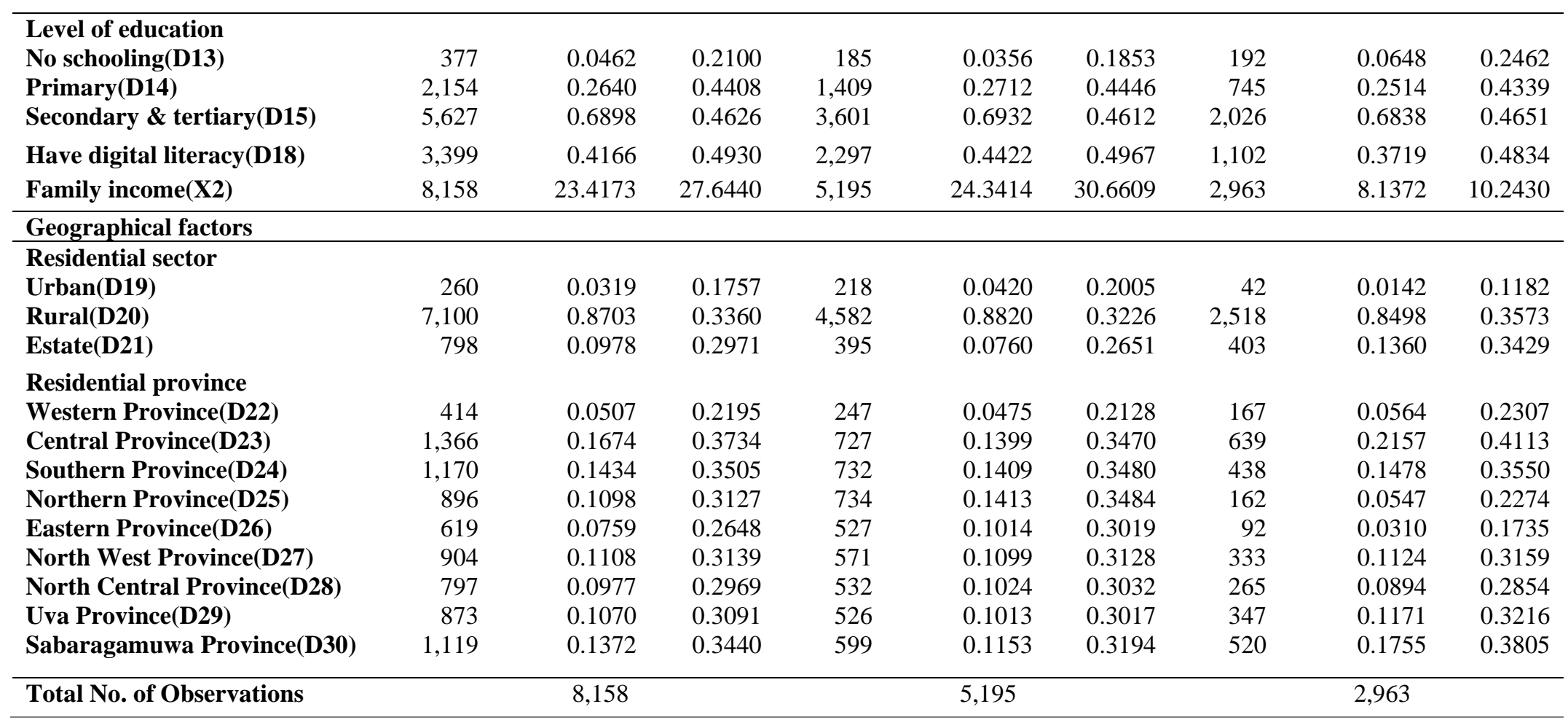

Source: Researcher's calculations using micro data, 2018

Notes: -

- The number of observations that become 1 of dummy variables have been included in No. of Obs. 


\section{Appendix C}

Table 03: Logistic regression models for self-employment choice in agricultural sector for total, male and female models

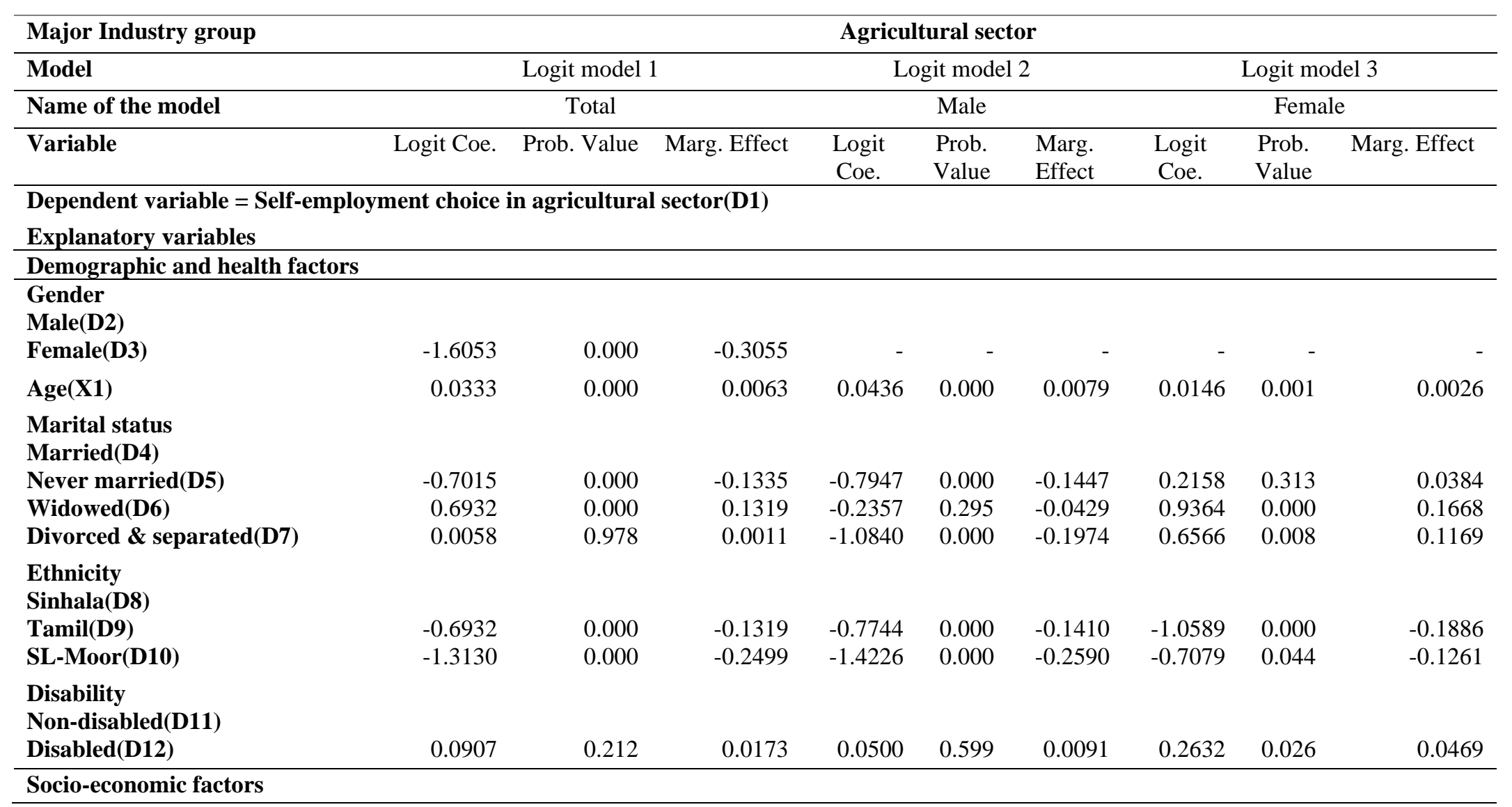


Level of education

No schooling(D13)

Primary(D14)

Secondary \& tertiary(D15)

\subsection{8}

0.8648

0.015

0.000

0.0633

0.1646

0.5151

1.0286

0.003

0.000

0.0938

0.1873

0.0386

0.6402

0.863

0.003

0.0069

Digital Literacy

No digital literacy(D17)

Have digital literacy(D18

Family income(X2)

0.2481

0.000

0.0472

0.1917

0.008

0.0349

0.3185

0.001

0.0567

Geographical factors

Residential sector
Urban(D19)

$\operatorname{Rural}(\mathbf{D 2 0})$

Estate(D21)

0.5347

$-1.0781$

0.000

0.000

0.1018

$-0.2052$

$-0.0007$

0.525

$-0.0001$

0.0479

0.000

0.0085

Residential province

Western Province(D22)

Central Province(D23)

Southern Province(D24)

Northern Province(D25)

Eastern Province(D26)

North West Province(D27)

North Central Province(D28)

Uva Province(D29)

Sabaragamuwa Province(D30)

Sample size

\begin{tabular}{l}
\hline Log likelihood \\
\hline Likelihood Ra \\
\hline Probability > \\
\hline Pseudo R2 \\
\hline \\
(C) (7) \\
\hline EY
\end{tabular}

\begin{tabular}{rrrrrrrrr}
0.2105 & 0.130 & 0.0401 & 0.7944 & 0.000 & 0.1447 & -0.3622 & 0.075 & -0.0645 \\
-0.2839 & 0.042 & -0.0540 & -0.2546 & 0.136 & -0.0464 & -0.4019 & 0.051 & -0.0716 \\
0.8616 & 0.000 & 0.1640 & 1.2062 & 0.000 & 0.2196 & 0.8317 & 0.010 & 0.1481 \\
0.5226 & 0.002 & 0.0995 & 0.6898 & 0.001 & 0.1256 & 1.5680 & 0.000 & 0.2793 \\
0.0378 & 0.793 & 0.0072 & 0.4418 & 0.015 & 0.0804 & -0.4887 & 0.026 & -0.0870 \\
0.6881 & 0.000 & 0.1310 & 1.2178 & 0.000 & 0.2217 & 0.0008 & 0.997 & 0.0001 \\
0.7325 & 0.000 & 0.1394 & 1.5606 & 0.000 & 0.2842 & -0.1480 & 0.500 & -0.0264 \\
0.1102 & 0.437 & 0.0210 & 0.2137 & 0.232 & 0.0389 & -0.1275 & 0.530 & -0.0227 \\
\hline \multicolumn{3}{c}{$-5,195$} & \multicolumn{3}{c}{-1556.2895} \\
\hline
\end{tabular}


Source: Researcher's calculations using micro data, 2018

Notes: -

- Reference category (Ref.) for total model: Being an employed person in agriculture sector who is a male, Sinhala, no schooling, married, nondisabled, living in urban sector in the Western Province and not having digital literacy.

- Reference category for male model: Being a male employed person in agricultural sector who is Sinhala, no schooling, married, non-disabled, living in urban sector in the Western Province and not having digital literacy.

- Reference category for female model: Being a female employed person in agricultural sector who is Sinhala, no schooling, married, nondisabled, living in urban sector in the Western Province and not having digital literacy.

- Statistically significant at $10 \%$ 


\section{Appendix D}

Table 04: Descriptive statistics for self-employment choice in industry sector for total, male and female models

\begin{tabular}{|c|c|c|c|c|c|c|c|c|c|}
\hline \multirow{3}{*}{$\begin{array}{l}\text { Major Industry group } \\
\text { Name of the model } \\
\text { Variable }\end{array}$} & \multicolumn{9}{|c|}{ Industry sector } \\
\hline & \multicolumn{3}{|c|}{ Total } & \multicolumn{3}{|c|}{ Male } & \multicolumn{3}{|c|}{ Female } \\
\hline & $\begin{array}{r}\text { No. of } \\
\text { Obs. }\end{array}$ & Mean/Prop. & Std. Dev. & $\begin{array}{l}\text { No. of } \\
\text { Obs. }\end{array}$ & Mean/Prop. & Std. Dev. & $\begin{array}{c}\text { No. of } \\
\text { Obs. }\end{array}$ & Mean/Prop. & Std. Dev. \\
\hline $\begin{array}{l}\text { Dependent variable } \\
\text { Self-employment choice(D1) }\end{array}$ & 1,830 & 0.2201 & 0.4144 & 1,093 & 0.1913 & 0.3934 & 737 & 0.2835 & 0.4508 \\
\hline \multirow{2}{*}{\multicolumn{10}{|c|}{$\begin{array}{l}\text { Explanatory variables } \\
\text { Demographic and health factors }\end{array}$}} \\
\hline & & & & & & & & & \\
\hline $\begin{array}{l}\text { Gender } \\
\text { Male(D2) } \\
\text { Female(D3) }\end{array}$ & $\begin{array}{l}5,713 \\
2,600\end{array}$ & $\begin{array}{l}0.6872 \\
0.3128\end{array}$ & $\begin{array}{l}0.4636 \\
0.4636\end{array}$ & $\begin{array}{l}- \\
-\end{array}$ & - & - & - & - & - \\
\hline $\operatorname{Age}(X 1)$ & 8,313 & 40.684 & 13.1336 & 5,713 & 40.6636 & 13.1190 & 2,600 & 40.7281 & 13.168 \\
\hline $\begin{array}{l}\text { Marital status } \\
\text { Married(D4) } \\
\text { Never married(D5) } \\
\text { Widowed(D6) } \\
\text { Divorced \& separated(D7) }\end{array}$ & $\begin{array}{r}6,037 \\
1,758 \\
313 \\
205\end{array}$ & $\begin{array}{l}0.7262 \\
0.2115 \\
0.0377 \\
0.0247\end{array}$ & $\begin{array}{l}0.4459 \\
0.4084 \\
0.1904 \\
0.1551\end{array}$ & $\begin{array}{r}4,351 \\
1,219 \\
59 \\
84\end{array}$ & $\begin{array}{l}0.7616 \\
0.2134 \\
0.0103 \\
0.0147\end{array}$ & $\begin{array}{l}0.4261 \\
0.4097 \\
0.1011 \\
0.1204\end{array}$ & $\begin{array}{r}1,686 \\
539 \\
254 \\
121\end{array}$ & $\begin{array}{l}0.6485 \\
0.2073 \\
0.0977 \\
0.0465\end{array}$ & $\begin{array}{l}0.4775 \\
0.4055 \\
0.2970 \\
0.2107\end{array}$ \\
\hline $\begin{array}{l}\text { Ethnicity } \\
\text { Sinhala(D8) } \\
\text { Tamil(D9) } \\
\text { SL-Moor(D10) }\end{array}$ & $\begin{array}{r}6,143 \\
1,585 \\
585\end{array}$ & $\begin{array}{l}0.7390 \\
0.1907 \\
0.0704\end{array}$ & $\begin{array}{l}0.4392 \\
0.3928 \\
0.2558\end{array}$ & $\begin{array}{r}4,149 \\
1,120 \\
444\end{array}$ & $\begin{array}{l}0.7262 \\
0.1960 \\
0.0777\end{array}$ & $\begin{array}{l}0.4459 \\
0.3970 \\
0.2677\end{array}$ & $\begin{array}{r}1,994 \\
465 \\
141\end{array}$ & $\begin{array}{l}0.7669 \\
0.1788 \\
0.0542\end{array}$ & $\begin{array}{l}0.4229 \\
0.3833 \\
0.2265\end{array}$ \\
\hline Disabled(D12) & 725 & 0.0872 & 0.2822 & 448 & 0.0784 & 0.2689 & 277 & 0.1065 & 0.3086 \\
\hline
\end{tabular}




\begin{tabular}{|c|c|c|c|c|c|c|c|c|c|}
\hline \multicolumn{10}{|l|}{ Level of education } \\
\hline No schooling(D13) & 107 & 0.0129 & 0.1127 & 58 & 0.0102 & 0.1003 & 49 & 0.0188 & 0.1360 \\
\hline Primary(D14) & 867 & 0.1043 & 0.3057 & 652 & 0.1141 & 0.3180 & 215 & 0.0827 & 0.2755 \\
\hline Secondary(D15) & 7,168 & 0.8623 & 0.3446 & 4,885 & 0.8551 & 0.3521 & 2,283 & 0.8781 & 0.3273 \\
\hline Tertiary(D16) & 171 & 0.0206 & 0.1419 & 118 & 0.0207 & 0.1422 & 53 & 0.0204 & 0.1413 \\
\hline Have digital literacy(D18) & 5,436 & 0.6539 & 0.4757 & 3,764 & 0.6588 & 0.4741 & 1,672 & 0.6431 & 0.4792 \\
\hline Family income(X2) & 8,313 & 40.559 & 74.4251 & 5,713 & 41.0344 & 83.181 & 2,600 & 18.9794 & 19.979 \\
\hline \multicolumn{10}{|l|}{ Geographical factors } \\
\hline \multicolumn{10}{|l|}{ Residential sector } \\
\hline Urban(D19) & 1,208 & 0.1453 & 0.3524 & 834 & 0.1460 & 0.3531 & 374 & 0.1438 & 0.3510 \\
\hline Rural(D20) & 6670 & 0.8024 & 0.3982 & 4,624 & 0.8094 & 0.3928 & 2,046 & 0.7869 & 0.4096 \\
\hline Estate(D21) & 435 & 0.0523 & 0.2227 & 255 & 0.0446 & 0.2065 & 180 & 0.0692 & 0.2539 \\
\hline \multicolumn{10}{|l|}{ Residential province } \\
\hline Western Province(D22) & 2,162 & 0.2601 & 0.4387 & 1,424 & 0.2493 & 0.4326 & 738 & 0.2838 & 0.4509 \\
\hline Central Province (D23) & 1,052 & 0.1265 & 0.3325 & 678 & 0.1187 & 0.3234 & 374 & 0.1438 & 0.3510 \\
\hline Southern Province (D24) & 1,074 & 0.1292 & 0.3354 & 771 & 0.1350 & 0.3417 & 303 & 0.1165 & 0.3209 \\
\hline Northern Province (D25) & 703 & 0.0846 & 0.2783 & 540 & 0.0945 & 0.2926 & 163 & 0.0627 & 0.2425 \\
\hline Eastern Province (D26) & 577 & 0.0694 & 0.2542 & 452 & 0.0791 & 0.2699 & 125 & 0.0481 & 0.2140 \\
\hline North Western Province & 1,101 & 0.1324 & 0.3390 & 708 & 0.1239 & 0.3295 & 393 & 0.1512 & 0.3583 \\
\hline (D27) & 375 & 0.0451 & 0.2076 & 247 & 0.0432 & 0.2034 & 128 & 0.0492 & 0.2164 \\
\hline North Central Province (D28) & 247 & 0.0297 & 0.1698 & 194 & 0.0340 & 0.1811 & 53 & 0.0204 & 0.1413 \\
\hline Uva Province (D29) & 1,022 & 0.1229 & 0.3284 & 699 & 0.1224 & 0.3277 & 323 & 0.1242 & 0.3299 \\
\hline \multicolumn{10}{|l|}{$\begin{array}{l}\text { Sabaragamuwa Province } \\
\text { (D30) }\end{array}$} \\
\hline Total No. of observations & & 8,313 & & & 5,713 & & & 2,600 & \\
\hline
\end{tabular}

Source: Author's calculations using micro data, 2018

Notes: -

- The number of observations that become 1 of dummy variables have been included in No. of Obs. 


\section{Appendix E}

Table 05: Logistic regression models for self-employment choice in the industry sector for total, male and female models

\begin{tabular}{|c|c|c|c|c|c|c|c|c|c|}
\hline \multirow{2}{*}{$\begin{array}{l}\text { Major Industry group } \\
\text { Model }\end{array}$} & \multicolumn{9}{|c|}{ Industry sector } \\
\hline & \multicolumn{3}{|c|}{ Logit model 4} & \multicolumn{3}{|c|}{ Logit model 5} & \multicolumn{3}{|c|}{ Logit model 6} \\
\hline Name of the model & \multicolumn{3}{|c|}{ Total } & \multicolumn{3}{|c|}{ Male } & \multicolumn{3}{|c|}{ Female } \\
\hline \multicolumn{10}{|c|}{ Dependent variable $=$ Self-employment choice in industry sector(D1) } \\
\hline \multicolumn{10}{|l|}{ Explanatory variables } \\
\hline \multicolumn{10}{|l|}{$\begin{array}{l}\text { Gender } \\
\text { Male(D2) }\end{array}$} \\
\hline $\operatorname{Age}(X 1)$ & 0.0363 & 0.000 & 0.0056 & 0.0292 & 0.000 & 0.0043 & 0.0490 & 0.000 & 0.0078 \\
\hline \multicolumn{10}{|l|}{$\begin{array}{l}\text { Marital status } \\
\text { Married(D4) }\end{array}$} \\
\hline \multicolumn{10}{|l|}{$\begin{array}{l}\text { Ethnicity } \\
\text { Sinhala(D8) }\end{array}$} \\
\hline Tamil(D9) & -0.0175 & 0.893 & -0.0027 & -0.2625 & 0.129 & -0.0383 & 0.4060 & 0.062 & 0.0647 \\
\hline SL-Moor(D10) & 0.7323 & 0.000 & 0.1135 & 0.3273 & 0.021 & 0.0477 & 1.5796 & 0.000 & 0.2517 \\
\hline \multicolumn{10}{|l|}{$\begin{array}{l}\text { Disability } \\
\text { Non-disabled(D11) }\end{array}$} \\
\hline Disabled(D12) & 0.1652 & 0.073 & 0.0256 & 0.1883 & 0.113 & 0.0275 & 0.0837 & 0.589 & 0.0133 \\
\hline
\end{tabular}




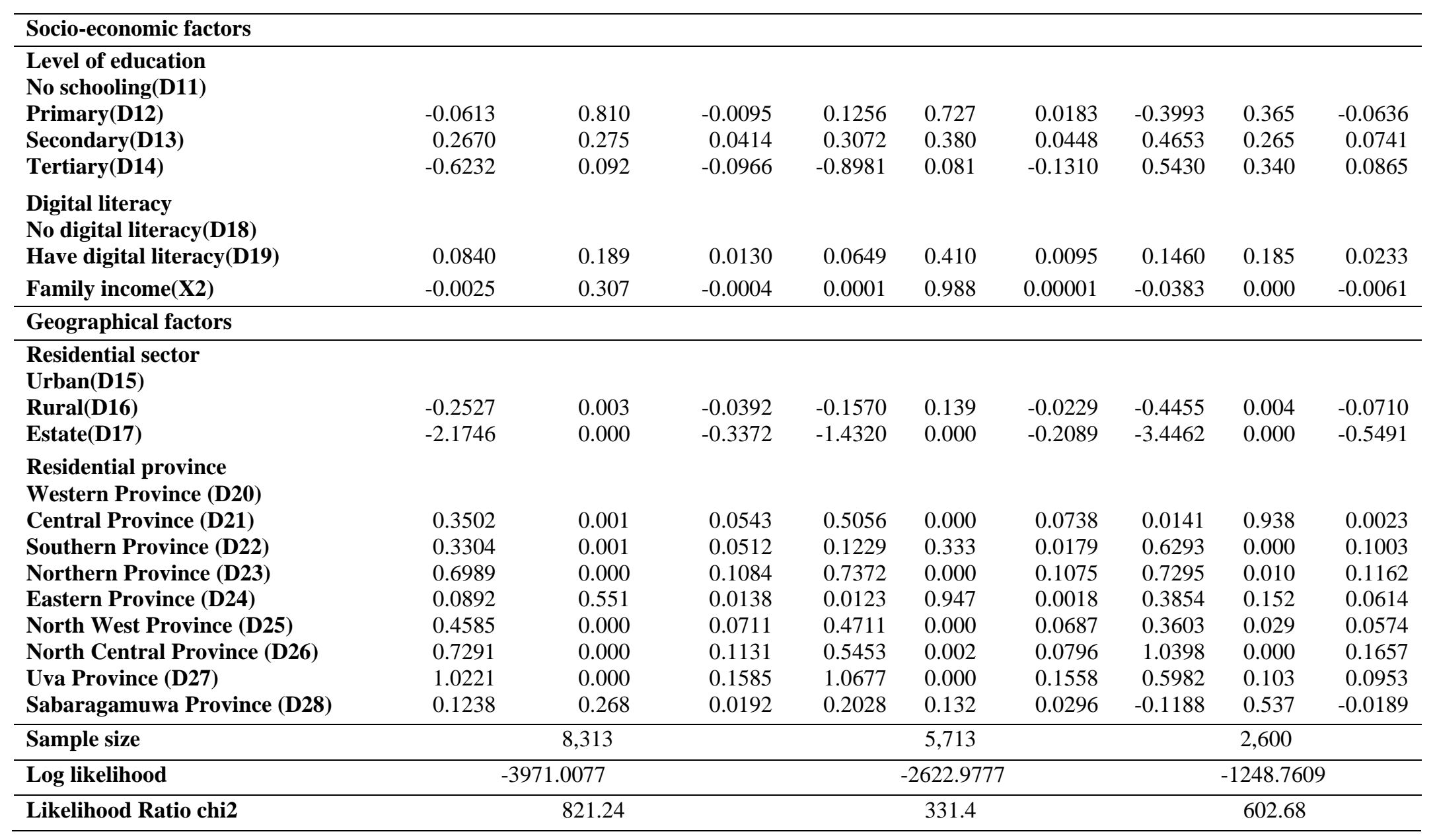




\begin{tabular}{lccc}
\hline Probability > chi2 & 0.0000 & 0.0000 & 0.0000 \\
\hline Pseudo R2 & 0.0937 & 0.0594 & 0.1944 \\
\hline
\end{tabular}

Notes: -

- Reference category (Ref.) for total model: Being an employed person in industry sector who is a male, Sinhala, no schooling, married, nondisabled, living in urban sector in the Western Province and not having digital literacy.

- Reference category for male model: Being a male employed person in industry sector who is Sinhala, no schooling, married, non-disabled, living in urban sector in the Western Province and not having digital literacy.

- Reference category for female model: Being a female employed person in industry sector who is Sinhala, no schooling, married, non-disabled, living in urban sector in the Western Province and not having digital literacy.

- Statistically significant at $10 \%$ 


\section{Appendix F}

Table 06: Descriptive statistics for self-employment choice in services sector for total, male and female models

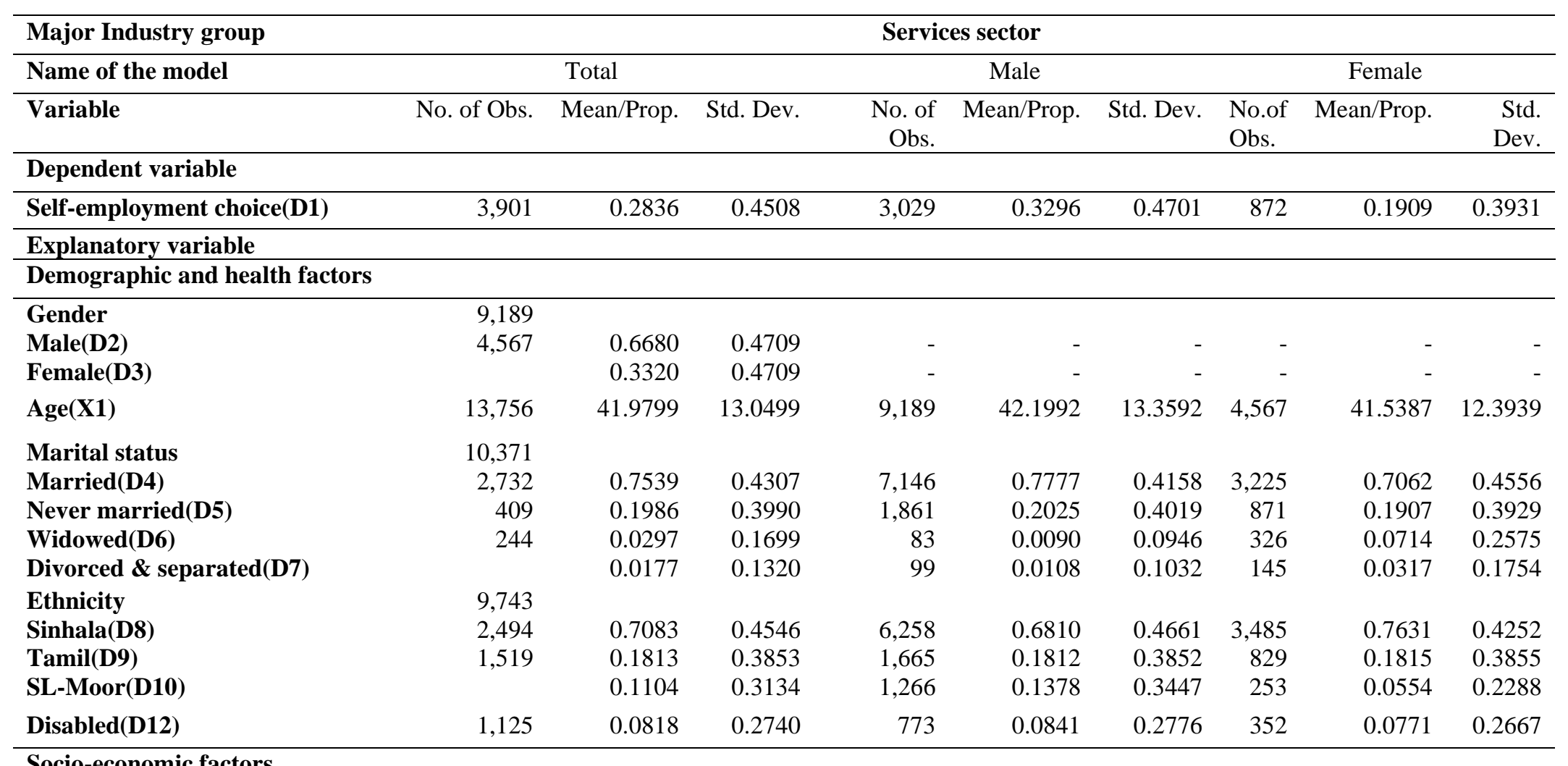

\footnotetext{
Socio-economic factors
} 


\begin{tabular}{|c|c|c|c|c|c|c|c|c|c|}
\hline Level of education & 138 & & & & & & & & \\
\hline No schooling(D13) & 1,035 & 0.0100 & 0.0997 & 70 & 0.0076 & 0.0870 & 68 & 0.0149 & 0.1211 \\
\hline Secondary(D15) & 1,431 & 0.8107 & 0.3918 & 7,795 & 0.8483 & 0.3588 & 3,357 & 0.7351 & 0.4414 \\
\hline Have digital literacy(D18) & 10,520 & 0.7648 & 0.4242 & 6,930 & 0.7542 & 0.4306 & \multirow[b]{2}{*}{3,590} & 0.7861 & 0.4101 \\
\hline Family income(X2) & 13,756 & 64.7893 & 154.5919 & 9,189 & 55.8471 & 173.1483 & & 34.3556 & 44.4510 \\
\hline Residential sector & 3,346 & & & & & & & & \\
\hline $\operatorname{Urban}(D 19)$ & 10,104 & 0.2432 & 0.4291 & 2,261 & 0.2461 & 0.4307 & 1,085 & 0.2376 & 0.4256 \\
\hline Rural(D20) & 306 & 0.7345 & 0.4416 & 6,692 & 0.7283 & 0.4449 & 3,412 & 0.7471 & 0.4347 \\
\hline Estate(D21) & & 0.0222 & 0.1475 & 236 & 0.0257 & 0.1582 & 70 & 0.0153 & 0.1229 \\
\hline \multicolumn{10}{|l|}{ Residential province } \\
\hline Western Province(D22) & 4,155 & 0.3021 & 0.4592 & 2,846 & 0.3097 & 0.4624 & 1,309 & 0.2866 & 0.4522 \\
\hline North Western Province(D27) & 1,384 & 0.1006 & 0.3008 & 889 & 0.0967 & 0.2956 & 495 & 0.1084 & 0.3109 \\
\hline North Central Province(D28) & 720 & 0.0523 & 0.2227 & 449 & 0.0489 & 0.2156 & 271 & 0.0593 & 0.2363 \\
\hline Uva Province(D29) & 547 & 0.0398 & 0.1954 & 351 & 0.0382 & 0.1917 & 196 & 0.0429 & 0.2027 \\
\hline Sabaragamuwa Province(D30) & 1,154 & 0.0839 & 0.2772 & 761 & 0.0828 & 0.2756 & 393 & 0.0861 & 0.2805 \\
\hline Total No. of observations & \multicolumn{3}{|c|}{13,756} & \multicolumn{3}{|c|}{9,189} & \multicolumn{3}{|c|}{4,567} \\
\hline
\end{tabular}

Source: Author's calculations using micro data, 2018

Notes: -

- The number of observations that become 1 of dummy variables have been included in No. of Obs. 


\section{Appendix G}

Table 07: Logistic regression models for self-employment choice in services sector for total, male and female models

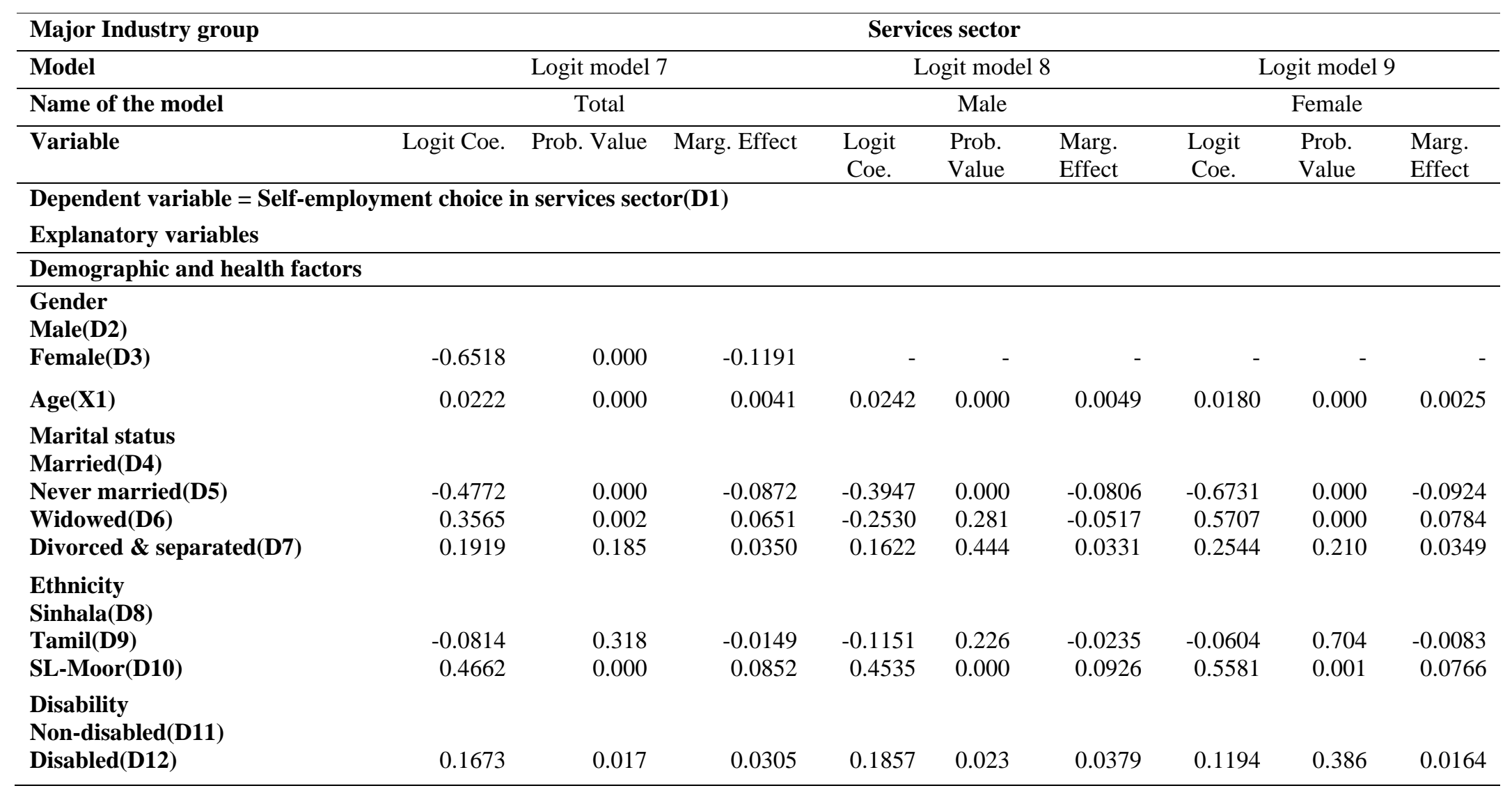


Socio-economic factors

\begin{tabular}{|c|c|c|c|c|c|c|c|c|c|}
\hline $\begin{array}{l}\text { Level of education } \\
\text { No schooling(D13) }\end{array}$ & & & & & & & & & \\
\hline Secondary(D15) & 0.4339 & 0.024 & 0.0792 & 0.3180 & 0.212 & 0.0650 & 0.6978 & 0.024 & 0.0958 \\
\hline Digital literacy & & & & & & & & & \\
\hline No digital literacy(D17) & & & & & & & & & \\
\hline Have digital literacy(D18) & -0.4004 & 0.000 & -0.0731 & -0.2882 & 0.000 & -0.0589 & -0.7070 & 0.000 & -0.0971 \\
\hline $\begin{array}{l}\text { Residential sector } \\
\text { Urban(D19) }\end{array}$ & & & & & & & & & \\
\hline Rural(D20) & 0.0889 & 0.095 & 0.0162 & 0.0260 & 0.668 & 0.0053 & 0.3007 & 0.009 & 0.0413 \\
\hline Estate(D21) & -0.1530 & 0.365 & -0.0279 & -0.0852 & 0.646 & -0.0174 & -0.2899 & 0.504 & -0.0398 \\
\hline $\begin{array}{l}\text { Residential province } \\
\text { Western Province(D22) }\end{array}$ & & & & & & & & & \\
\hline North Western Province(D27) & 0.3782 & 0.000 & 0.0691 & 0.3720 & 0.000 & 0.0760 & 0.4004 & 0.006 & 0.0550 \\
\hline North Central Province(D28) & 0.1722 & 0.070 & 0.0315 & 0.0253 & 0.823 & 0.0052 & 0.4152 & 0.016 & 0.0570 \\
\hline Uva Province(D29) & 0.1887 & 0.083 & 0.0345 & 0.2169 & 0.092 & 0.0443 & 0.1053 & 0.608 & 0.0145 \\
\hline Sabaragamuwa Province(D30) & 0.0944 & 0.246 & 0.0172 & 0.1200 & 0.202 & 0.0245 & 0.0337 & 0.837 & 0.0046 \\
\hline Sample size & & 13,756 & & & 9,189 & & & 4,567 & \\
\hline Log likelihood & & .3504 & & & -5459.5155 & & & -1969.5382 & \\
\hline Likelihood Ratio chi2 & & 1488.92 & & & 731.13 & & & 514.44 & \\
\hline
\end{tabular}




\begin{tabular}{lccc}
\hline Probability > chi2 & 0.0000 & 0.0000 & 0.0000 \\
\hline Pseudo R2 & 0.0908 & 0.0628 & 0.1155 \\
\hline
\end{tabular}

Notes: -

- Reference category (Ref.) for total model: Being an employed person in services sector who is a male, Sinhala, no schooling, married, nondisabled, living in urban sector in the Western Province and not having digital literacy.

- Reference category for male model: Being a male employed person in services sector who is Sinhala, no schooling, married, non-disabled, living in urban sector in the Western Province and not having digital literacy.

- Reference category for female model: Being a female employed person in services sector who is Sinhala, no schooling, married, non-disabled, living in urban sector in the Western Province and not having digital literacy.

- Statistically significant at $10 \%$ 